\title{
An annotated checklist of the endemic Carabidae (Coleoptera) of Egypt
}

\author{
Mahmoud S. Abdel-Dayem \\ Cairo University, Faculty of Science, Entomology Department, Giza, 12613-Egypt. \\ Plant Protection Department, College of Food and Agricultural Sciences, King Saud University P.O. Box 2460 Riyadh, 11451, Saudi Arabia. \\ E-mail: msabdeldayem@sci.cu.edu.eg
}

\begin{abstract}
Endemic species are usually not very widespread in their distribution, but are only found in a particular region and nowhere else in the world. Because of this, they are of great conservation concern. A checklist of the endemic carabid beetles of Egypt was compiled and updated from published and unpublished records including long-term surveys. As far as can be ascertained, there are 39 valid carabid species and subspecies from 28 genera that are endemic to Egypt including Sinai. These represent about $16.3 \%$ of the total carabid fauna recorded from the country, and belong to five subfamilies: Brachininae, Cicindelinae, Harpalinae, Scaritinae, and Trechinae. I provide notes about type localities, depositories and distribution.
\end{abstract}

\section{INTRODUCTION}

More than ever before, endangered and endemic species are used by conservationists to set priorities for establishing protected areas (Brooks et al. 2006). Species checklists are helpful tools in the fields of natural science. They serve to consolidate our level of knowledge and at the same time reveal areas in need of further investigation.

In the first half of the twentieth century, Schatzmayr (1936) published the first information about the species composition of carabid beetles of Egypt, while Alfieri (1976) published the latest comprehensive list of most families of Egyptian beetles, including Carabidae. Alfieri summarized what was known about distribution in his fundamental faunistic work. The catalogues of several families have been updated and revised since then, but the lack of a complete and readily accessible list is a major difficulty when this type of information is needed, in particular in systematic, biogeographical or ecological studies. In the last thirty years, new data on taxonomy have been supplemented with information on species distributions (Abdel-Dayem 1998; 2009; Abdel-Dayem et al. 2003) and faunal composition of various areas in Egypt with differing bioregions (El- Moursy et al. 2001; Semida et al. 2001; El-Gharbawy and Salem 2003; Abdel-Dayem 2004).

The aim of this study is to compile an annotated list of the endemic carabid species known from Egypt, integrating all published sources, records in Egyptian Insect Reference Collections and long-term field surveys. In addition, it aims to provide a status quo and to track changes from the last comprehensive lists (Schatzmayr 1936; Alfieri 1976).

\section{Materials ANd Methods}

\section{Data Sources}

This checklist is mostly based on available literature and specimens rather than on extensive new taxonomic work. The data on endemic carabid species have been combined from published data from a variety of different sources, a detailed examination of all the specimens preserved in Egyptian Insect Reference Collections (EIRCs), and longterm field surveys carried out by the author between 1991 and 2009. The collected specimens from these surveys have been identified and deposited in the insect reference collection of the Entomology Department, Faculty of Science, Cairo University, Giza, Egypt (CUC).

\section{Taxonomic Considerations}

The checklist includes all endemic species of carabid beetles known to occur or to have occurred within the political boundaries of Egypt. Endemic species are indigenous (precinctive) species based on their current taxonomic status in Egypt and known from no other area.

\section{Arrangement}

The list is arranged systematically to genus level and alphabetically thereafter. The classification and nomenclature of endemic carabid beetles follow Löbl and Smetana (2003). For the species, the most recent combination followed by the author name, year and page number (s) of original citation are given. The type locality (followed by Governorate and bioregion between parentheses) and the type depository, from collections, original description or publications, are given after the name, where available; a question mark notes cases which are doubtful. In some cases (especially when the available data are only taken from the original description), specific type localities are not known and thus bioregion or just 'Egypt' is given.

Each species has been attributed to one or more of the seven bioregions of Egypt (Figure 1) based on the literature (Alfieri 1976; Abdel-Dayem 1998; 2009; AbdelDayem et al. 2003) and unpublished field data. After each bioregion, each species has also been provided with a list of localities in Egypt from which it has been recorded. The localities are arranged alphabetically and mainly based on literature and data labels of specimens actually examined 
by the author.

\section{Revision Procedures}

Species have been declared to be in the checklist only based on one or more voucher specimens in EIRCs or a reliable published record. The initial step was a compiled list of all the species recognized in Csiki (1928), Schatzmayr and Koch (1933, 1934), Schatzmayr (1936), Alfieri (1976), Löbl and Smetana (2003), and Abdel-Dayem (1998, 2009). This preliminary list was evaluated and documented by checking it, species by species, aligned with the specimens preserved in EIRCs. Additionally, the list was supplemented and refined by consulting the major reference works and selected other publications, as suitable. The annotations in the checklist are based on all of these sources.

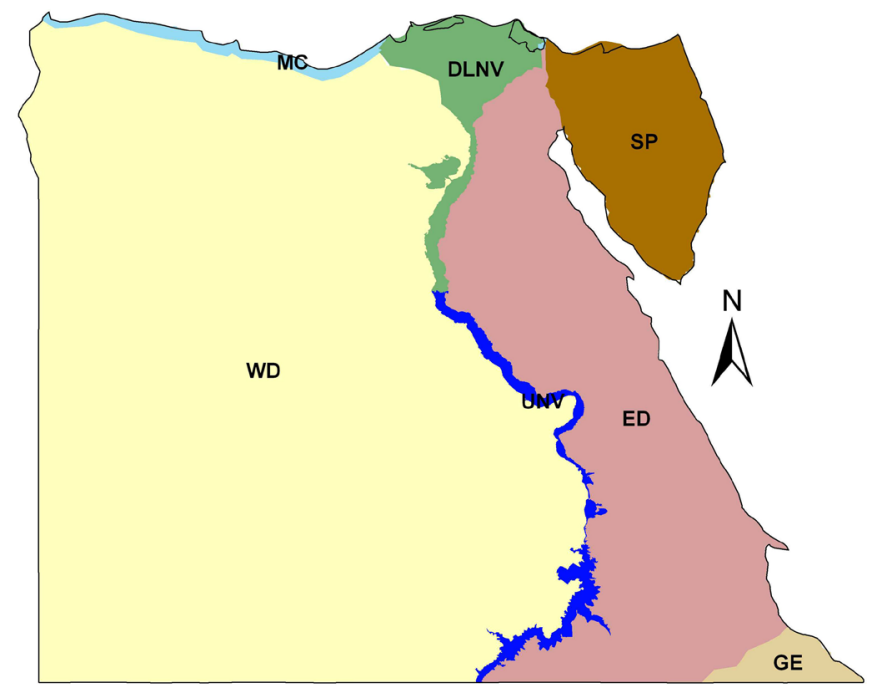

FIGURE 1. Map of bioregions in Egypt. Legend: DLNV, Delta and Lower Nile Valley; ED, Eastern Desert; GE, Gebel Elba; MC: Mediterranean Coast; SP, Sinai Peninsula; UNV, Upper Nile Valley; WD, Western Desert.

\section{Acronyms of depositories}

ALFC - Alfieri Collection, Plant Protection Department, Faculty of Agriculture, Al Azhar University, Cairo, Egypt. BNHMF - Basel Natural History Museum, G. Frey Collection, Switzerland.

CUC - Cairo University Collection, Entomology Department, Faculty of Science, Cairo University, Giza, Egypt.

HNHM - Hungarian National History Museum, Budapest, Hungary.

MAC - Ministry of Agriculture Collection, Insect Classification and Surveying, Plant Protection Research Institute, Agricultural Research Center, Dokki, Giza, Egypt. MCNM - Natural History Museum of Milan, Italy.

MHNB - Museum of Natural History, Humboldt

University, Berlin, Germany. MNHN - Museum National d'Histoire Naturelle, Paris, France.

SMNH - Swedish Museum of Natural History, Stockholm, Sweden.

USNM - National Museum of Natural History,

Smithsonian Institution, Washington, D.C, USA.

ZMMU - Zoological Museum of Moscow Lomonosov University, Moscow, Russia.

Abbreviations used for bioregion in Egypt
DLNV, Delta and Lower Nile Valley; ED, Eastern Desert; GE, Gebel Elba; MC, Mediterranean Coast; SP, Sinai Peninsula; UNV, Upper Nile Valley; WD, Western Desert.

\section{RESULTS AND DISCUSSION}

At present, there are 39 species of endemic carabid beetles known from Egypt, comprising 28 genera in five subfamilies, and representing $16.3 \%$ of the total carabid fauna in Egypt. This high endemic percentage is due mainly to the Harpalinae $(8.3 \% ; 20$ species in 17 genera), Trechinae $(4.6 \% ; 11$ species in 7 genera), Scaritinae $(2.1 \%$, five species in two genera), Brachininae $(0.8 \%$, two species in one genus), and Cicindelinae $(0.4 \%$, one species in one genus). The most numerous genus is Cilvina (4), while Tachyura has three species, and Brachinus, Chlaenius, Microlestes and Porotachys include two species each. The remaining genera have only one endemic species.

\section{The Checklist}

Subfamily: Cicindelinae Latreille, 1802

Tribe: Cicindelini Latreille, 1802

Subtribe: Cicindelina Latreille, 1802

Genus: Cephalota Dokhtouroff, 1883

1. Cephalota (Taenidia) tibialis tibialis (Dejean, 1822)

Cicindela tibialis Dejean, 1822: 55

Type locality: Port Said (Port Said, MC)

Type depository: MNHN

Distribution: MC: Burg El-Arab, Dekhiela, Matrouh,

Port Said, Ras El-Bar. SP: Zaranik.

Subfamily: Brachininae Bonelli, 1810

Tribe: Brachinini Bonelli, 1810

Genus: Brachinus Weber, 1801

2. Brachinus latipennis Peyerimhoff, 1907: 8

Type locality: Sinai (Southern Sinai, SP)

Type depository: MNHN

Distribution: SP: El-Hessua Oasis, Gebel Mussa, Karm Alam, Wadi Feiran, Wadi Gena, Wadi Hebran, Wadi Isla. WD: Dakhla Oasis.

3. Brachinus (Cnecostolus) pseudocruciatus Reitter, 1909: 30

Type locality: Alexandria (Alexandria, MC)

Type depository: HNHM

Distribution: DLNV: Cairo. MC: Alexandria.

Subfamily: Scaritinae Bonelli, 1810

Tribe: Clivinini Rafinesue, 1815

Subtribe: Clivinina Rafinesue, 1815

Genus: Clivina Latreille, 1802

4. Clivina goniostoma Putzeys, 1866: 128

Type locality: Egypt

Type depository: MNHN

Distribution: no record other than the type specimen

(Schatzmayr, 1936)

5. Clivina kochi Schatzmayr, 1936: 30

Type locality: Kirdasa (Giza, DLNV)

Type depository: MCNM

Distribution: DLNV: Beni Youssef, Cairo, El Wasta, Giza, Kafr Hakim, Kirdasa, Mansouriya, Mataria, Pyramids, Talbiya, Sakkara. UNV: Assuit.

6. Clivina nitida Mjöberg, 1905: 3

Type locality: Aswan (Aswan, UNV)

Type depository: SMNH 
Distribution: Aswan is the only known locality for this species.

7. Clivina tutancamon Schatzmayr, 1936: 30

Type locality: Barrage (Qalubyia, DLNV)

Type depository: MCNM

Distribution: DLNV: Barrage, Maadi, Shirbin.

Tribe: Dyschiriini W. Kolbe, 1880

Genus: Dyschirius Bonelli, 1810

8. Dyschirius (Dyschiriodes) aida Schatzmayr, 1936: 34, 37

Type locality: Ismailia (Ismailia, ED)

Type depository: MCNM

Distribution: known only from the type locality.

Subfamily: Trechinae Bonelli, 1810

Tribe: Bembidiini Stephens, 1827

Subtribe: Bembidiina Stephens, 1827

Genus: Bembidion Latreille, 1802

9. Bembidion (Microserrullula) aegyptiacum Dejean, 1831: 90

Type locality: Egypt

Type depository: MNHN

Distribution: DLNV: Barrage, Cairo, Helwan, Kafr Shukr, Katta, Marg, Mataria, Mazghouna, Rod El Farag, Shubra, Toura. SP: Wadi El Ghazal. UNV: Assuit, Aswan, Idfu, Luxor, Toshka, Wadi Halfa.

10. Bembidion (Notaphocampa) moursyi Abdel-Dayem, 1998: 189

Type locality: Toshka (Aswan, UNV)

Type depository: CUC

Distribution: UNV: Khur Galal, Toshka, Wadi Alaqi.

Subtribe: Tachyina Motschulsky, 1862

Genus: Helenaea Schatzmayr and Koch, 1934

11. Helenaea torretassoi Schatzmayr and Koch, 1934: 23

Type locality: El Tor (Southern Sinai, SP).

Type depository: MCNM

Distribution: known only from the type locality.

Genus: Lymnastis Motschulsky, 1862

12. Lymnastis sinaiticus Schatzmayr, 1936: 59

Type locality: Wadi Isla (Southern Sinai, SP)

Type depository: MCNM

Distribution: known only from the type locality

Genus: Porotachys Netolitzky, 1914

13. Porotachys efflatouni (Schatzmayr and Koch, 1934)

Tachys efflatouni Schatzmayr and Koch, 1934: 20

Type locality: Wadi Aideb (Red Sea, GE)

Type depository: MAC

Distribution: known only from the type locality

14. Porotachys shahinei (Schatzmayr and Koch, 1934)

Tachys shahinei Schatzmayr and Koch, 1934: 20

Type locality: Wadi Anid (Red Sea, GE)

Type depository: MAC

Distribution: no record other than the type specimen.

Genus: Tachys Dejean, 1821

15. Tachys (Tachys) centromaculatus aegyptiacus

Schatzmayr and Koch, 1934: 13

Type locality: Mex (Alexandria, MC)

Type depository: MCNM

Distribution: DLNV: Borgash, Cairo, Helwan, Lake Qaroun, Mansouriya, Toura. ED: Ismailia, Nefisha. MC: Alexandria, Kafr El Batikh, Le Cap Mariout. SP: Zaranik. WD: Siwa Oasis.

Genus: Tachyura Motschulsky, 1862

16. Tachyura (Tachyura) akkadi Abdel-Dayem, 2009: 72
Type locality: Wadi Aideb, (Red Sea, GE)

Type depository: MAC

Distribution: no record other than the type specimen.

17. Tachyura (Tachyura) fadli Abdel-Dayem, 2009: 72

Type locality: Salouga Island Protectorate (Aswan, UNV)

Type depository: CUC

Distribution: recorded only from the type locality.

18. Tachyura (Tachyura) sinaitica (Schatzmayr, 1936)

Tachys sinaiticus Schatzmayr, 1936: 55, 58

Type locality: Wadi Isla (Southern Sinai, SP)

Type depository: MCNM

Distribution: SP: Wadi Isla, Wadi Zaouatina.

Tribe: Pogonini Laporte, 1834

Genus: Sirdenus Dejean, 1828

19. Sirdenus (Syrdenopsis) extensus Chaudoir, 1871: 35

Type locality: Red Sea coast (without giving specific locality)

Type depository: MNHN

Distribution: Schaum collected this species from Egypt on the banks of the Red Sea (Chaudoir, 1871); it has not been collected since the original description.

Subfamily: Harpalinae Bonelli, 1810

Tribe: Chlaeniini Brullé, 1834

Subtribe: Chlaeniina Brullé, 1834

Genus: Chlaenius Bonelli, 1810

20. Chlaenius (Nectochlaenius) canariensis sinaiticus Peyerimhoff, 1907: 6

Type locality: Wadi El Ain (Southern Sinai, SP)

Type depository: MNHN

Distribution: SP: Wadi Arbaein, Wadi Budz, Wadi El Ain, Wadi Geghir, Wadi Hebran, Wadi Isla.

21. Chlaenius (Trichochlaenius) tenellus Klug, 1832: pl. 24

Type locality: Alexandria (Alexandria, MC)

Type depository: MHNB

Distribution: DLNV: Badrashien, Cairo, El Wasta, Giza, Sakkara, Talbiya. MC: Alexandria, Port Said. UNV: Assuit, Luxor.

Tribe: Cyclosomini Laporte, 1834

Subtribe: Cyclosomina Laporte, 1834

Genus: Tetragonoderus Dejean, 1829

22. Tetragonoderus (Tetragonoderus) aegypticus Jedlička, 1952: 80

Type locality: Egypt

Type depository: HNHM

Distribution: no record other than the type specimen.

23. Tetragonoderus (Tetragonoderus) assuanensis Mjöberg, 1905: 2

Type locality: Aswan (Aswan, UNV)

Type depository: SMNH

Distribution: not collected since it was described.

Subtribe: Masoreina Chaudoir, 1870

Genus: Aephnidius W.S. MacLeay, 1825

24. Aephnidius rutilus (Schaum, 1863)

Masoreus rutilus Schaum, 1863: 79

Type locality: Egypt

Type depository: MHNB

Distribution: DLNV: Cairo, Fayoum, Kafr Hakim, Kirdasa. MC: Mersa Matrouh, Salloum. SP: Arish, Romani.

Tribe: Harpalini Bonelli, 1810

Subtribe: Harpalina Bonelli, 1810

Genus: Siopelus Murray, 1859 
25. Siopelus laevicollis N. Ito, 1995: 157

Type locality: Arabian Desert (probably Sinai Peninsula, according to Dr. Fritz Hieke)

Type depository: MHNB

Distribution: no record other than the type specimen.

Subtribe: Stenolophina Kirby, 1837

Genus: Anthracus Motschulsky, 1850

26. Anthracus boops (J.R. Sahlberg, 1900)

Acupalpus boops J.R. Sahlberg, 1900: 140

Type locality: Pyramids (Giza, DLNV)

Type depository: HNHM

Distribution: DLNV: Abu Rawash, Alag, Cairo, Ezbet El Nakhle, Fayoum, Giza, Helwan, Kirdasa, Maadi, Marg, Massara, Mazghouna, Pyramids, Rod El Farag, Sakkara, Toura, Waraq. MC: Alexandria.

Genus: Dicheirotrichus Jacquelin du Val, 1857

27. Dicheirotrichus (Pelagophilus) punicus aegyptiacus Schatzmayr, 1936: 80

Type locality: Mediterranean coast from Hammam to Alexandria (MC)

Type depository: MCNM

Distribution: MC: Abu Qir, Amrieh, Burg El Arab, King Mariout, Mex, Ras El Bar.

Tribe: Lebiini

Subtribe: Apenina

Genus: Platytarus Fairmaire, 1850

28. Platytarus faminii petroffi Antoine, 1933: 98

Type locality: Alexandria (Alexandria, MC)

Type depository: MNHN

Distribution: DLNV: Abu Rawash, Barrage, Beni Mazar, Cairo, Giza, Marg, Talbiya. MC: Alexandria, Tewfikieh.

Subtribe: Dromiina Bonelli, 1810

Genus: Calodromius Reitter, 1905

29. Calodromius henoni (Bedel, 1907)

Dromius henoni Bedel, 1907: 277

Type locality: Cairo (Cairo, DLNV)

Type depository: MNHN

Distribution: DLNV: Cairo, Giza, Helmieh, Helwan, Marg, Zagazig, Zeitoun.

Genus: Dromius Bonelli, 1810

30. Dromius (Dromius) alfierii Peyerimhoff, 1927: 220

Type locality: Sinai

Type depository: MNHN

Distribution: ED: Suez. SP: Gebel Asmar, Wadi Rayig,

Wadi Rished.

\section{Genus: Microlestes Schmidt-Göbel, 1846}

31. Microlestes fulvus Alfieri, 1976: 26

Type locality: Vicinity of Pyramids (Giza, DLNV)

Type depository: ALFC

Distribution: there no other record than the type specimen.

32. Microlestes sinaiticus Alfieri, 1976: 26

Type locality: Wadi Godirate (Northern Sinai: SP)

Type depository: USNM

Distribution: no record other than the type specimen.

\section{Genus: Paradromius Fowler, 1887}

33. Paradromius (Manodromius) cylindraticollis

(Peyerimhoff, 1927)

Dromius cylindraticollis Peyerimhoff, 1927: 218

Type locality: Kafr El Sheikh (Sakha, DLNV)

Type depository: MNHN

Distribution: DLNV: Sakha, Shirbien.

Genus: Psammodromius Peyerimhoff, 1927
34. Psammodromius noctivagus Peyerimhoff, 1927: 222

Type locality: Amrieh (Alexandria, MC)

Type depository: MNHN

Distribution: MC: Alexandria, Amrieh, Dekhielah, Hammam, Mersa Mariout, Matrouh.

Subtribe: Lionychina Jeannel, 1948

Genus: Tilius Chaudoir, 1876

35. Tilius obscurellus obscurellus (Dejean, 1831)

Dromius obscurellus obscurellus Dejean, 1831: 362

Type locality: Egypt

Type depository: MNHN

Distribution: DLNV: Barrage, Cairo, El Roda, Helwan, Kafr Shukr, Mansouriya, Shubra, Wardan. UNV: Assuit, Aswan, Luxor, Kuashtamma, Wadi Halfa.

Tribe: Odacanthini Laporte, 1834

Genus: Eucolliuris Liebke, 1931

36. Eucolliuris aegyptiaca (Jedlička, 1960)

Colliuris aegyptiaca Jedlička, 1960: 597

Type locality: Cairo (Cairo, DLNV)

Type depository: BNHMF

Distribution: known only from the type locality.

Tribe: Pterostichini Bonelli, 1810

Genus: Poecilus Bonelli, 1810

37. Poecilus (Ancholeus) pharao (Lutshnik, 1916)

Platysma pharao Lutshnik, 1916: 92

Type locality: Egypt

Type depository: Originally this species was described as Feronia conformis (Dejean, 1828), but the latter name is homonym of another species of Pterostichus. Platysma pharao Lutshnik is a replacement name. The type depositor of Feronia conformis is MNHN. Distribution: DLNV: Abu Rawash, Ayat, Badrashin, Barrage, Birqash, Cairo, Dahshour, El Aksas, Gezira, Giza, Helwan, Kafr Hakim, Kirdasa, Lake Qaroun, Maadi, Mansoura, Massara, Pyramids, Sakkara, Talbiya, Toura. MC: Amrieh, Mex, Ramleh. SP: Sharm El-Sheikh. UNV: Assuit, El Balyana, Luxor, Qena, Wadi Halfa. WD: Kharga Oasis.

Tribe: Sphodrini Laporte, 1834

Subtribe: Atranopsina Baehr, 1982

Genus: Platyderus Stephens, 1827

38. Platyderus (Platyderus) ferrantei Reitter, 1909: 29

Type locality: Cairo (Cairo, DLNV)

Type depository: HNHM

Distribution: It is only known from type locality.

Tribe: Zuphiini Bonelli, 1810

Subtribe: Zuphiina Bonelli, 1810

Genus: Zuphium Latreille, 1806

39. Zuphium(Zuphium) olens kochi Schatzmayr, 1936: 106 Type locality: Egypt

Type depository: MCNM

Distribution: DLNV: Cairo, Fayoum, Lake Qaroun, Marg, Mazghouna, Pyramids, Sakkara Toura. ED: Qantara. MC: Alexandria, Mex, Ramleh.

Lymnastis sinaiticus and Bembidion moursyi were described from Egypt by Schatzmayr (1936) and Abdel-Dayem (1998), respectively, but they have been overlooked in the Catalogue of Palaearctic Coleoptera (Kopecky 2003) and does not mentioned in the systematic list of extant ground beetles of the world (Lorenz, 2005). The distribution of Porotachys efflatouni and Porotachys 
shahinei is wrongly cited as Sinai by Kopecky (2003): Schatzmayr and Koch (1934) described these two species from the Gebel Elba area (Wadi Aideb and Wadi Anid, respectively), and they have not been recorded from Sinai (Abdel-Dayem 2004) or any other locality until now.

There is no indication of where the holotypes of Bembidion aegyptiacum, Clivina goniostoma, Aephnidius rutilus, Poecilus pharao, Tetragonoderus aegypticus, Tilius obscurellus obscurellus, and Zuphium olens kochi were collected in Egypt, so it is difficult to determine their type localities.

The following 15 taxa have been described from Egypt, but there are no subsequent records other than the type specimens. Clivina goniostoma, C. nitida, Dyschirius aida, Eucolliuris aegyptiaca, Lymnastis sinaiticus, Microlestes fulvus, M. sinaiticus, Platyderus ferrantei, Porotachys efflatouni, P. shahinei, Siopelus laevicollis, Sirdenus extensus, Tachyura akkadi, T. fadli, Tetragonoderus aegypticus, and T. assuanensis.

The following carabid species have been considered as endemic to Egypt by at least one author, but should not be categorized as such:

1. Abacetus longiusculus Chaudoir, 1869. Although this species was recorded from Senegal and Sudan (Schatzmayr 1936), Bousquet (2003) reported it as endemic to Egypt.

2. Bembidion karounense Jedlička, 1959. This species is synonym of $B$. latiplaga Chaudoir, 1850 (Abdel-Dayem 1998).

3. Chlaenius cruciatus Dejean, 1831. While the type locality is Senegal, and it has been recorded from Sudan and Egypt (Schatzmayr 1936) and Libya (Le-Quellec and Ringenbach 2004), Kirschenhofer (2003) reported it as endemic to the Egyptian fauna.

4. Chlaenius laeviplaga laeviplaga Chaudoir, 1876. Although its type locality is Ethiopia, Kirschenhofer (2003) reported this species as endemic to Egypt.

5. Chlaenius pharaonis (Motschulsky, 1865). According to Lorenz (2005) this may be a synonym of Chlaenius (Epomis) circumscriptus (Duftschmid, 1812).

6. Clivina erythropyga Putzeys, 1866. Balkenohl (2003) listed this species as endemic to Egypt, and $C$. madagascariensis from Yemen; meanwhile, he listed $C$. natalensis as a synonym of $C$. madagascariensis. Kult (1959) and Lorenz (2005) treated C. erythropyga and $C$. madagascariensis as proper different species. However, according to Bruneau de Miré (1990) C. erythropyga only separtaed from C. madagascariensis by its redish brown elytral apex and that is why he has the opinion that $C$. erythropyga is a subspecies of $C$. madagascariensis. Also Kult (1959) states that, apart from the colour of the apex, C. erythropyga is very similar to $C$. natalensis. According to Ron Felix (unpublished data), there are no differences between the male genitalia of $C$. madagascariensis, C. natalensis and C. erythropyga from the museum in Tervuren. Maybe C. erythropyga is only a colour variation of $C$. madagascariensis as several specimens of the latter taxon may have a dark red tip or cross band at the apex of the elytra. After he studying several publications like the above mentioned and others, it is clear that C. erythropyga has a rather vast distribution in Africa: from Guinee Bissau (Serrano, 1996) till East and Southwest Africa (Kult, 1959), and according to Mateu (1966) in whole Africa. Therefore, apart from taxonomic status of this species, C. erythropyga is not endemic to Egypt.

7. Lophyridia fimbriata (Dejean, 1831). This was reported wrongly as endemic to Egyptian fauna (Puchkov and Matalin 2003). It was described from Senegal, and has been recorded from Sudan and Egypt as Cicindela dongalensis Klug, 1832; clearly it is not a species endemic to the Egyptian fauna (Abdel-Dayem et al. 2003).

8. Microlestes levipennis longipennis Motschulsky, 1859. Egypt was indicated as the type locality for the holotype (ZMMU) of this species, and it has never been collected from Egypt since its description. Thus it is likely that this species comes from Anglo Egyptian Sudan (Schatzmayr 1936). Based on this comment, most likely this taxon is doubtful for the Egyptian fauna.

9. Porotachys zulficari (Schatzmayr and Koch, 1934). This was recorded as endemic to Egypt (Kopecky 2003). However, it can no longer be considered to be endemic since I have received specimens from the United Arab Emirates (from Ron F. Felix in 2009); these specimens were identical to the holotype of $P$. zulficari preserved in the MAC Collection.

10. Tachys dimediatus alexandrinus Schatzmayr and Koch, 1934. This was recorded as endemic to Egypt (Kopecky 2003), but now has been reported from Libya (Le-Quellec and Ringenbach 2004).

11. Tachys torretassoi Schatzmayr and Koch, 1934. This was described from Suez, and has been considered to be endemic to Egypt (Kopecky 2003); however, it has been recorded from Palestine (Schatzmayr 1936) and the Emirates (Felix 2009).

12. Zabrus ventricosus (C. Zimmermann, 1931). This was reported as endemic to Egypt (Serrano and Andújar, 2003), but now has been recorded from Libya (Le-Quellec and Ringenbach 2004).

For more than 35 years, Alfieri (1976) remained the principal source of data on the Egyptian beetle fauna, while progressively becoming outdated. A new, revised and updated list of the endemic carabid species is provided here, recognizing 39 valid endemic species. This list does not claim to be complete, but provides an updated listing. Further continuous observations will be necessary to complete the species list.

Even more differences are apparent when compared to the last checklist compiled by Alfieri (1976), possibly due to nomenclatural and taxonomic problems, wrongly reported species, new described species, and distribution records from the Egyptian fauna or other adjacent countries. Undoubtedly, there are gaps in this list, particularly with respect to localities. As anticipated, a list of this nature is a reflection of collectors and their preferences and research projects. There are, for example, many fewer published papers or records available on the carabid fauna of the Western Desert in Egypt. Moreover, the taxonomic status of some Egyptian endemic species is questionable. This concern is especially for taxa described by Jedlička and Schatzmayr, which probably have never been revised. These need serious taxonomic work in future. Thirty nine species represents a significant number of endemic taxa; further surveys and distribution analysis are needed to illustrate the considerable significance of the country for 
insect conservation. I hope that this work will be a basis for future taxonomical and ecological investigations of the Egyptian endemic species.

ACKNOWLEDGMENTS: I am grateful to the Insect Reference Collections at Ain Shams University (Prof. Hasan H. Fadl), Al Azhar University (Dr. Mohamed Kamel), Cairo University, Entomological Society of Egypt (Dr. Hany A. Abd-El Gawad), and Ministry of Agriculture (Prof. Kamal H. El-Akkad) for permission to check all the carabid specimens that formed the basis for this study. I thank also Ron F. Felix (Netherlands) for providing Porotachys zulficari specimens collected from United Arab Emirates. I thank the Museum of Natural History in Humboldt University, Berlin (Bernd Jaeger and Manfred Uhlig); the Hungarian Natural History Museum in Budapest (Gyozo Szél); the National Museum of Natural History in Bulgaria (Dr. Borislav Guéorguiev); the Muséum National d'Histoire Naturelle in Paris (Azadeh Taghavian); and Zoological Museum of Moscow (Dr. Boris Kataev) for providing the data of type material collected from Egypt. The author is grateful to Dr Francis Gilbert, School of Biology, Nottingham University, Nottingham, UK; for linguistic reviewing and commenting on the manuscript. I am deeply indebted to Cairo University for supporting me during all my field trips and providing all facilities during lab work. The author is indebted to the two reviewers whose comments and suggestions helped to improve an earlier version of this article.

\section{Literature Cited}

Abdel-Dayem, M.S. 1998. The Egyptian species of Bembidion Latreille, 1802 (Coleoptera, Carabidae). Bulletin of the Entomological Society of Egypt 76: 181-214.

Abdel-Dayem, M.S. 2004. Diversity and spatial distribution of ground and tiger beetles (Carabidae, Coleoptera) in the Sinai peninsula, Egypt. Bulletin of the Entomological Society of Egypt 81: 57-80.

Abdel-Dayem, M.S. 2009. Two new species of the ground beetle genus Tachyura Motschulsky, 1862 from Egypt (Coleoptera: Carabidae: Trechinae: Bembidiini). Zoology in the Middle East 48: 71-74.

Abdel-Dayem, M.S., M.S. EL-Hawagry and S.A. Hassan. 2003. A review of the Egyptian species of tiger beetles (Coleoptera, Carabidae, Cicindelinae). Bulletin of the Entomological Society of Egypt 80: 193217.

Alfieri, A. 1976. The Coleoptera of Egypt (Monograph). Mémoires de la Société Entomologique d' Egypte 5: i-xvi, 1-361.

Antoine, M. 1933. Notes d'entomologie marocaine. XIV. Carabiques nouveaux ou intéressants (Ins. Coléopt.). Bulletin de la Société des Sciences Naturelles du Maroc 13: 69-101.

Balkenohl, M. 2003. Archostemata-Myxophaga-Adephaga; Family Carabidae: Subfamily Scaritinae; p. 219-234 In I. Löbl and A. Smetana (ed.). Catalogue of Palaearctic Coleoptera. Volume 1: Denmark: Stenstrup, Apollo Books.

Bedel, L. 1907. Catalogue raisonné des Coléoptères du nord de l'Afrique. (Maroc, Algérie, Tunisie et Tripolitanie) avec notes sur la faune des Îles Canaries et de Madère, première partie. Paris: Société Entomologique de France. 402 pp.

Bousquet, Y. 2003. Archostemata-Myxophaga-Adephaga; Family Carabidae: Subfamily Harpalinae: Tribe Abacetini; p. 346-347 In I. Löbl and A. Smetana (ed.). Catalogue of Palaearctic Coleoptera. Volume 1: Denmark: Stenstrup, Apollo Books.

Brooks, T.M., R.A. Mittermeier, G.A.B. da Fonseca, J. Gerlach, M. Hoffmann, J.F. Lamoreux, C.G. Mittermeier, J.D. Pilgrim, and A.S.L. Rodrigues. 2006. Global biodiversity conservation priorities. Science 313:58-61.

Bruneau de Miré, Ph., 1990, Les Coléoptères Carabiques du Tibesti. Annls. Soc. ent. Fr. (N.S.), 26, 4: 499-554.

Chaudoir, M. de. 1871. Essai monographique sur le groupe des pogonides. Annales de la Société Entomologique de Belgique 14: 21-61.

Csiki, E. 1928. Carabidae II. Mormolycinae et Harpalinae I (Pars 97); p. 1-226 In W. Junk and S. Schenkling (ed.). Coleopterorum Catalogus. Volume II. Berlin: W. Junk.

Dejean, P.F.M.A. 1822. New species; 91-134, pl. 6-10 In P.A. Latreille and P.F.M.A. Dejean Histoire naturelle et iconographie des insects coléoptères d' Europe. 1-e livraison, Paris: Crevot.

Dejean, P.F.M.A. 1831. Species général des coléoptères, de la collection de M. le Comte Dejean. Tome cinquième. Paris: Méquignon-Marvis. viii $+883 \mathrm{pp}$.

El-Moursy, A.A., M.S. El-Hawagry, M.S. Abdel-Dayem and H.H. Fadl. 2001. Insect diversity in Zaranik Protectorate, Northern Sinai, Egypt. Egyptian Journal of Natural History 3: 62-80.

El-Gharbawy, A.A. and M.M. Salem. 2003. Occurrence and distribution of family Carabidae (Coleoptera) in Egypt. Al-Azhar Bulletin of Science $14(2): 53-63$.

Felix, R.F.F.L. 2009. Order Coleoptera, family Carabidae. Arthropod fauna of the UAE 2:66-141.

Ito, N. 1995. A new genus and two new species of the Selenophori group
(Harpalini, Carabidae, Coleoptera). Japanese Journal of Systematic Entomology 1(2): 153-159.

Jedlička, A. 1952. Neue Carabiden aus der Sammlung des ungarischen naturwissenschaftlichen Museums in Budapest (Col.). Annales Historico-Naturales Musei Nationalis Hungarici 43 (2): 79-93.

Jedlička, A. 1960. Neue Carabiden aus der Sammlungen des Museums Frey (Col.). Entomologischen Arbeiten aus dem Museum G. Frey 11: 587-598.

Kirschenhofer, E. 2003. Archostemata-Myxophaga-Adephaga; Family Carabidae: Subfamily: Harpalinae: Tribe: Chlaeniini; p. 347-356 In I. Löbl and A. Smetana (ed.). Catalogue of Palaearctic Coleoptera. Volume 1: Denmark: Stenstrup, Apollo Books.

Klug, J.C.F. 1832. Decas tertia; Sheets a-f, pl. xxi-xxx In Symbolae Physicae, seu icones et descriptiones insectorum, quae ex itinere per Africam borealem et Asiam occidentalem Friderici Guilelmi Hemprich et Christiani Godofredi Ehrenberg studio novae aut illustratae redierunt. 42 unn. Sheets+50 pl., Berlin: Mittler.

Kopecky, T. 2003. Archostemata-Myxophaga-Adephaga; Family Carabidae: Subfamily: Trechinae: Tribe Bembidiini: Subtribe Tachyina; p. 273-280 In I. Löbl and A. Smetana (ed.). Catalogue of Palaearctic Coleoptera. Volume 1: Denmark: Stenstrup, Apollo Books.

Kult, K., 1959, Revision of the African Species of the old Genus Clivina Latr. Revue de Zoologie et de Botanique Africaines LX, 1-2: 172-225.

Le-Quellec, J.L. and J.C. Ringenbach: Beetles of Libya. 16 June 2004. Electronic website accessible at http://jcringenbach.free.fr. Accessed on 4 October 2011.

Löbl, I. and A. Smetana. 2003. Catalogue of Palaearctic Coleoptera. Volume 1: Archostemata-Myxophaga-Adephaga. Copenhagen: Apollo Books. $819 \mathrm{p}$.

Lorenz, W., 2005, Systematic list of extant Ground Beetles of the world. (Insecta Coleoptera "Geadephaga": Trachypachidae and Carabidae incl. Paussinae, Cicindelinae, Rhysodinae), second edition. Tutzing: W. Lorenz, 530p.

Lutshnik, V.N. 1916. Analecta synonymica de quibusdam Platysmatinis (Coleoptera, Carabidae). II. Russkoe Entomologicheskoe Obozrenie 16: 92.

Mateu, J., 1966, Coléoptères Carabiques récoltés par J. Mateu dans l'Ennedi et au Nord-Tchad. Bulletin de l'I.F.A.N., T. XXVIII, sér. A, 4: 1501-1544.

Mjöberg, E. 1905. Coleoptera of the Swedish Zoological Expedition to Egypt and the White Nile. Fam. Cicindelidae and Carabidae; p. 1-20 In K.W. Appelberg (ed.). Results of the Swedish Zoological Expedition to Egypt and White Nile 1901 under the direction of L.A. Jägerskiöld.10a: Uppsala: the Library of the Royal University.

Motschulsky, V. de. 1859. Insectes nouveaux ou peu connus des basins de la Méditerranée et de la mer Noire jusqu'à la mer Caspienne. Etudes Entomologiques 8: 119-144.

Motschulsky, V. de. 1865. Énumération des nouvelles espèces de Coléoptères rapports de ses voyages. 4-éme article. (Suite). Bulletin de la Société Impériale des Naturalistes de Moscou 37: 297-355.

Peyerimhoff, P. de. 1907. Liste des Coléoptères du Sinai. L'Abeille, Journal d'Entomologie 31: 1-55.

Peyerimhoff, P. de. 1927. Carabides égyptiens (Colépt.). Bulletin de la Société Royale Entomologique d'Egypte 19: 218-223.

Puchkov, A.V. and A.V. Matalin. 2003. Archostemata-MyxophagaAdephaga; Family Carabidae: Subfamily Cicindelinae; p. 99-118 In I. Löbl and A. Smetana (ed.). Catalogue of Palaearctic Coleoptera. Volume 1: Denmark: Stenstrup, Apollo Books.

Putzeys, J.A.A.H. 1866. Révision générale des clivinides. Annales de la Société Entomologique d'Belgique 10: 1-242.

Reitter, E. 1909. Espèces nouvelles de Coléoptères égyptiens. Bulletin de la Société Entomologique d'Egypte 1: 29-32.

Sahlberg, J.R. 1900. Bestimmungs-Tabellen der europäischen Coleopteren. XLI. Heft. Enthaltend Carabidae. Abtheilung: Harpalini und Licinini. Verhandlungen des Naturforschenden Vereines in Brünn 38: 33-155.

Schatzmayr, A. 1936. Risultati scientifici della spedizione entomologica di S.A.S. il Principe Alessandro della Torre e Tasso in Egitto e nella penisola del Sinai. XII. Catalogo ragionato dei Carabidi finora noti d'Egitto e del Sinai. Pubblicazioni del Museo entomologico Pietro Rossi 14(1): 1-114.

Schatzmayr, A. and C. Koch. 1933. Risultati scientifici della spedizione entomologica di S.A.S. il Principe Alessandro della Torre e Tasso in Egitto e nella Penisola Sinai. I. Descrizione di un nuovo genere appartenente alla sezione dei Clivinia (Coleotteri: CarabidaeScaritinae). Bulletin de la Société Royale Entomoloique d'Égypte 17: 121-125.

Schatzmayr, A. and C. Koch. 1934. Risultati scientifici della spedizione entomologica di S.A.S. il Principe Alessandro della Torre e Tasso in Egitto e nella Penisola Sinai. IV. Tachys Steph. Bolletino della Societe Adriatica di Scienze Naturali Trieste 33: 1-23.

Schaum, H.R. 1863. Beiträge zur Kenntniss einiger CarabicinenGattungen. Berliner Entomologische Zeitschrift 7: 67-92. 
Semida, F.M., M.S. Abdel-Dayem, S.M. Zalat and F.S. Gilbert. 2001. Habitat heterogeneity and altitudinal gradients in relation to beetle diversity in South Sinai, Egypt. Egyptian Journal of Biology 3: 137-146.

Serrano, A.R.M., 1996, Estudo de Coleópteros Carabídeos (Coleoptera: Carabidae) da Guiné-Bissau. I. Cymbionotinae, Siagoninae, Hiletinae, Scaritinae e Apotominae (1). Boletim da Sociedade Potuguesa de Entomologia, 162, Vol. Vi-12: 149-171.

Serrano, J. and A. Andújar. 2003. Archostemata-Myxophaga-Adephaga; Family Carabidae: Tribe Zabrini: Subtribe Zabrina; p. 568-573 In I. Löbl and A. Smetana (ed.). Catalogue of Palaearctic Coleoptera. Volume 1: Denmark: Stenstrup, Apollo Books.
RECEIVED: December 2011

ACCEPTED: February 2012

PUBLISHED ONLINE: February 2012

EDITORIAL RESPONSIBILITY: Matthew Smart 